\title{
Appropriate Technology and Economic Development of Emerging Economies - A Myth or a Reality
}

\author{
Durgamohan Musunuri \\ Institute for International Management and Technology, Gurgaon, India
}

\begin{abstract}
The appropriateness of technology being purchased, transferred, and used by emerging economies has been an issue raised at different world forums and discussed with no appreciable change in the state of affairs. However there are changes occurring due to the innovative ways in which the same technology is put to use resulting in products that have found easy acceptance amongst the users. This development questions the premise on which appropriateness of technology is judged. The paper reviews the existing literature on appropriate technology and makes an attempt to identify the characteristics of an appropriate technology and validates these characteristics through the case study approach. The research points out two different facets of use of technology, one in which high technology and the products based on it are adopted without any modification and accepted too. The other is the use of high technology to develop products that are appropriate but are very different from the products for which the high technology was initially developed. Whether the technology is high or basic should not be a debatable issue, but technology that finds acceptance in the emerging economies becomes appropriate. Only those technologies have found acceptance, which take into consideration the economic, cultural, and environmental conditions prevailing in these emerging economies. The findings and the conclusions of the paper have implications for the policy makers as well as business enterprises of not only emerging economies but also of industrialised countries.
\end{abstract}

Keywords: Appropriate Technology, Emerging Economies, Technology Transfer, Dual Economy.

\section{INTRODUCTION}

7 echnology is a word often used in various domains, especially in the realm of economic development, and is considered as the key that opens various doors which then leads a society or country on to the path of economic development. It is regarded as the most important differentiator between the developed "North" and the developing "South" or between the developed economies and the emerging economies.

The UNCTAD draft on "International Code on the Transfer of Technology" (the draft TOT Code) describes technology as "systematic knowledge for the manufacture of a product, for the application of a process or for rendering of a service."(Transfer of Technology, 2001). Merriam-webster.com (2014) defines technology as "the practical application of knowledge especially in a particular area / a manner of accomplishing a task especially using technical processes, methods, or knowledge."

Journal of Technology

Management for Growing Economies

Vol. 5 No. 1 April 2014 pp. 51-62

\section{CHITKARA 司 UNIVERSITY}

C) 2014 by Chitkara University. All Rights Reserved. 

governments, administrators and politicians continue to believe that it is the lack of technology, which is responsible for low rates of economic growth and the subsequent poverty that prevails in the world. Ranis (2011) stated that "Human development, in combination with technology, yields economic growth which, in turn, is necessary to generate further advances in human development". Consequently, the emerging economies embarked on a journey of economic development with the help of technology transferred from the developed countries. Even though this journey did not yield the requisite results on account of the technology used, which was developed in the capitalrich countries, countries from the developing and underdeveloped "south" continued the journey. Emerging economies are no exception to this. In spite of this dismal outcome of adoption of these capital-intensive technologies, more and more countries are joining this bandwagon without actually thinking about the appropriateness of the technology and the suitability of the technology that is transferred from the developed "north".

The advent of globalisation brought with it a technological invasion from the developed world to the emerging economies. It led to a different kind of industrialisation of the emerging economies, whereby the emerging economies became the production centres especially for those goods and services that were hitherto produced in the industrialised countries. This is not a result of deliberate steps taken by the emerging economies, but is a result of business need to sustain the profitability of the business enterprises from the developed world. In this era of globalisation, the appropriate technology concept has taken a back seat especially in countries like India, experiencing high economic growth amongst the emerging economies. However, globalisation has no way changed the scenario and the "dual economy", as propounded by Schumacher (1989) continues to prevail and rather became well entrenched. The differences in these economies have become more acute now.

Keeping the above mentioned facts and issues in mind, this paper attempts to critically evaluate the appropriateness of the technology being purchased, transferred, and used by the emerging economies and the need to develop appropriate applications based on the same technologies, resulting in new and innovative products that cater to the needs of the consumers in a better manner.

\section{REVIEW OF LITERATURE}

While discussing about the problem of production Schumacher (1989) talks about the belief of human beings that "the problem of production has been solved" is erroneous. This is a result of their inability to distinguish between capital and income and consequently the modern industrial systems consume 
the base (capital), which are natural resources, on which these systems are erected. These systems live on irreplaceable capital that is treated as income. The author further argues that human beings still have to learn to live peacefully with nature.

With regards to the development of emerging economies (also called third world countries), Schumacher (1989) stated that a 'dual economy' has appeared in all emerging economies due to the economic development measures undertaken by these countries, which are mainly based on technology from the developed countries to the emerging economies. Dual economy means - two ways of life, one which earns many times over the other, leading the rich becoming richer and the poor becoming poorer. The need for appropriate technology arises from the emergence of this 'dual economy'. Schumacher (1993) further propounded the concept of intermediate technology, which is neither the indigenous technology, the $£ 1$ technology of the emerging economies nor the highly capital-intensive technology, the $£ 1000$ technology of the developed countries, but a $£ 100$ technology. The nomenclature used varies such as appropriate technology, labour-intensive technology, alternative technology, low-cost technology. However, for the purpose of analysis the term appropriate technology is used in this paper.

Jauhari (2012) writing about technology communities concluded that Apple's success is attributable to outstanding design features, very functional software, portability, and a dynamic approach in creating applications resulting in a very distinctive user experience. Further Apple has fostered strategic alliances with numerous stakeholders. If appropriate technology platforms are deployed, there will be enormous power in the hands of handheld devices. The author also points out the importance of engaging with the stakeholders while developing technologies that makes them appropriate.

The concept of appropriate technology, which is defined as 'technology that is appropriate to the environmental, cultural, and economic situation it is intended for'. Hence, appropriate technology requires smaller amount of resources, lower cost and has less impact on the environment. The position paper referred to further clarifies that appropriate technology is one that takes into account technical, financial, environmental, institutional, and community factors into consideration. Also, it may not be cheap or suitable only for the emerging economies (Strategy, 2008).

Mahatma Gandhi was one of the pioneers of appropriate technology, much before the world recognised its importance and usefulness. He talked about promoting village industries and advocated the philosophy of production by the masses versus mass production. He urged that the abundant resource, i.e., labour that India possesses should be utilized. This is embedded in the concept

Journal of Technology Management for Growing Economies, Volume 5, Number 1, April 2014
Appropriate Technology and Economic Development 

relevant even today.

Akubue (2000) referring to the U.S. Agency for International Development (USAID) 1976 proposal to the U. S. Congress said that the use of capitalintensive technology has contributed to the development of dual economies consisting of a small percentage of well-paid workers with a large percentage of workers poorly paid and experiencing stagnation. This dual economy resulted in increasing migration of people to cities, who continued to live in pathetic conditions. Jequier (1979), as quoted by Akubue (2000) stated that modern technologies and appropriate technologies are complimentary to each other and are not contradictory. This is especially true in the globalised world, where there is a need for these two technologies to co-exist and prosper together.

UNCTAD series on issues in International Investment Agreements (IIA) and stated that a lion's share of the modern technology is developed by transnational corporations (TNCs), whose principal research and development activity is located in industrialised countries. This creates an asymmetry between technology possession and the place of technological need. This clearly shows that the modern technology is developed without actually considering the needs of the emerging economies, who are also the customers of this technology. This brings to the forefront the question of appropriateness of technology, as it is developed in complete isolation from one of the potential places of use (Transfer of Technology 2001).

In the course of discussing about technology and emerging economies, Narayana (2003) argued that emerging economies (developing countries) need technology with a human face, which does not make human beings redundant but helps them to become more productive. The author also talks about the "dual economy" - a modern sector and a non-modern sector, the modern sector with its patterns of living and working similar to those of industrialised countries and the non-modern sector with distinctly unsatisfactory living and working, which is in the process of accelerating decay. The author further argues in favour of appropriate technology, which should fulfil the conditions of three A's test - affordable, accessible and appropriate. Affordable means for those people who live on US \$ 1 per day, accessible to those people belonging to marginal communities in emerging economies and appropriate keeping in view the socio, cultural and economic needs of the people, environmentally sustainable, and can be made, developed and managed by the same people who use it.

As regards to the import of technology by emerging economies, Haug (1992) stated that there has been a tremendous effort made on part of the 
emerging economies to import technology from the industrialised countries to bridge the economic gap that exists between the emerging economies and the industrialised countries, but with little success. The reasons cited by him for this situation are as follows:

1. Lack of developed infrastructure and market - Lack of infrastructure and internal market capable of absorbing and sustaining developed technology. Emerging economies lacked technological infrastructure that support systems, which are needed for the successful absorption of technology like hardware, technical education, capability to carry out research and development, ability to maintain the technology, etc.

2. Inappropriate technology - The technology imported is not suitable for the needs of the emerging economies. As the technology is developed for own usage and not for sale, apart from the environmental factors prevailing in industrialized countries are way different from those prevailing in emerging economies, this imported technology becomes inappropriate.

3. Packaging of technology - Technology is transferred as a technology package, which includes machinery, building plans, management expertise, and production plans. These packages included obsolete or irrelevant technology that does not meet the needs of the emerging economies.

4. Failure to develop indigenous technological skills - Emerging economies adopted the strategy of technology at any cost, which resulted in a faster rate of technology imports leaving little time to assimilate these technologies and develop the relevant expertise.

5. Absence of a technological development plan - Lack of coherent and strategic plan of technological development, especially after World War II, when many countries became independent.

Further strengthening the case of the absence of a technological plan, Solsona (2013) stated that the developing countries lacked a well-structured technological policies based on their local capacities, their cultural characteristics and the economic and human resources they possess. A technology that is not understood and that does not take into account the complex framework of interactions between cultural, economic, social, political factors will not succeed generally in emerging economies.

At the initial stage of development of new technologies, Hubbe (2007) recommends that scientists should ask themselves a set of questions about the possible uses of their scientific inventions. These are:

1. "Does the technology on which I am working require long shipping distances, increased vulnerability to diseases, or risk of unintended consequences?"

Journal of Technology Management for Growing Economies, Volume 5, Number 1, April 2014
Appropriate Technology and Economic Development 
Musunuri, D.
2. "Does the technology on which I am working minimize, or at least not increase, the release of carbon dioxide or consumption of fossil fuels?"

3. "If implemented, is the technology on which I am working likely to pose risks to current or future generations? Is there a reliable way to minimize environmental hazards associated with it?"

The author concludes that the scientist (the person developing a new technology) should provide some guidance to others about selection of technologies; otherwise, the inertia of scientific progress will take human beings in unwanted directions.

A technology plan that automatically finds a place in literature is the "walking on two legs" policy of Mao Tse-Tung of China, wherein technological dualism was adopted - one for urban areas based on use of capital intensive technologies and the other for rural areas based on use of appropriate technologies to develop the rural industries (Perera and Mahakalanda 2008). The use of appropriate technologies resulted in utilisation of abundant local resources and created employment opportunities in the rural areas. It was responsible for the avoidance of urban-rural polarisation. The application of appropriate technologies was in the areas of energy, shelter, transport, water and sanitation, food and agriculture, ICTs, etc. Carmichael (2000) as quoted by Perera and Mahakalanda (2008) advocates the use of open source software in the education sector versus proprietary software, as affordable and appropriate. Open source Software can easily be adapted to the local needs, once the locals are able to learn the developments skills, they could continue to develop the system further. Examples in this context are "Moodle", a free and open source educational course management tool, "Grameen Phone" available in Bangladesh. They also defined appropriate technology as "a technology that focuses on achieving human priorities and being originated anywhere in the world but with high adoptability to the context concerning the present balance of ecological and socio-cultural systems."

Knowledge, a key factor necessary for economic development, is often not directly considered in the discussions about appropriate technologies. However, Sas (2004) puts knowledge in the correct perspective and said that scientific knowledge and indigenous knowledge are viewed as diametrically opposite to each other. Scientific knowledge is considered as global, centralised and technically oriented as compared to indigenous knowledge, which is local knowledge unique to a particular culture. Quoting Sillitoe (2002) that knowledge is a continuum and at one end is the indigenous knowledge and at the other end is the scientific knowledge with many intergradations between these two, the author stated that the issues raised by these different definitions

Journal of Technology Management for Growing Economies, Volume 5, Number 1, April 2014 
of knowledge should be considered while introducing technology in the emerging economies.

The failure of conventional science and technology policies in emerging economies as discussed by Daudpota (2001) in a paper titled "Intermediate Technology - An appropriate Developmental Path". The author talks about the difference in the nature of relationship between Science and Technology and society in the emerging economies in comparison to industrialised economies. The difference exists because of the distribution of population between in urban and rural areas, which is 95\%: $5 \%$ in industrialised countries versus $20 \%-30 \%$ : 70\%-80\% in developing countries. The author further discusses the issues India faced in adopting the western model by setting up large capital intensive industry, setting up of institutions of excellence in technical education, using of high-yielding varieties of rice and wheat, which needed expensive inputs of fertilizers, irrigation, etc resulting in lopsided development that resulted in the "dual economy". The author quotes that the biogas technology, which uses animal dung, vegetable matter, etc and turns it into manure and generates methane gas that can be used for cooking or for running generators. This technology not only uses local materials, but creates huge employment in the rural areas as compared to large scale, capital intensive chemical fertiliser plants.

The World Bank found that the use of modern technology in emerging economies is increasing by leaps and bounds. In the 10 year span between early 1990s and the early 2000s, the index that summarises for example: computers and mobile phones per capita, patents and scientific papers published, import of high-technology and capital goods, number of hours of electricity per day, etc, showed an increase of $160 \%$ in poor countries with less than $\$ 900$ per capita income to $100 \%$ in middle - income countries with $\$ 900-\$ 11,000$ per capita income and $77 \%$ in industrialised countries with $\$ 11,000$ above of per capita income. This shows that poor and middle-income countries are fast bridging the technology gap between them and the industrialised countries. But the main issue is the adoption of technologies, which is slow in poor and middle-income countries. The bank concluded that out of 67 examples of adoption of high technology only 6 were able to capture $50 \%$ of the national market, against all technologies adopted in industrialised countries reaching 50\% market share. Emerging economies are able to access technology, but are poor in putting this technology to use. The capacity to absorb technologies depends on education; R\&D; financial system; the quality of Government. (Economist, 2008). 


\section{DISCUSSION}

The debate of high technology versus appropriate technology continues, but then there is a considerable increase in the access to high technologies and the transfer of high technology, which is being witnessed in the last two decades. The emerging economies in general and the BRICs countries in particular are the recipients of these technologies. The dual economy continues to exist and these countries have not found an appropriate solution to erase the differences that exists. The present situation is no different from what was prevailing before the advent of globalization. These emerging economies were earlier seeking high technologies, which were difficult to procure even if one was willing to pay a price, to cater to the needs of their citizens. Now the technologies are made available, hence the difficulty in procuring has been partially mitigated, but to cater to the needs of the world.

But alongside these developments, another development that is noteworthy is the use of high technology to develop products that are relevant and appropriate for the people of the emerging economies. Even though this is just a beginning, but it can result in a paradigm shift in the way high technology will be used in the future by emerging economies.

The process of replicating the economic development model of the industrialised countries in emerging economies through rapid industrialisation based on technology transfer could not succeed in emerging economies, even though various international organizations like United Nations Conference on Trade and Development (UNCTAD) have been making efforts to ease technology transfer and the positive impact of globalization on technology transfer.

Technology of the industrialised countries was developed keeping in view the environmental factors prevailing in those countries and consequently is suitable for them is not the technology for the emerging economies, as they do not in any way have the same environmental factors.

The debate and discussion on appropriateness of technology continues, but from the existing literature it is easily discernible that the "three A's test" could be used as a litmus test to identify a technology as appropriate. Also, appropriate technology is one that takes into account the economic, social, cultural and environmental situation of the country, where it is intended to be used. Thereby, it becomes successful and appropriate.

Many examples are existing which confirm that even products of high technology have found ready acceptance in emerging economies.

A classic example is the advent of mobile phones, a high technology device and the popularity of mobile phones In India: the number of mobile phone subscribers in India stood at 0.5548 billion with $54 \%$ of these subscribers hailing from rural areas and the rest from cities and towns (IBN Live, 2013), 
while total population of India is 1.21 billion (Census, 2011) This shows that the mobile phone, a high-tech device is accepted by both the tech-savvy population and the not so tech-savvy population of India. This is due to the fact that Indians are very collectivist in nature. Hofsted (2013) states that India with a score of 48 on the cultural dimension "Individualism" is a society with clear collectivist traits. This translates into a high preference for belonging to a larger social framework. The mobile phone finds a cultural fit and also is in tune with the economic environment. In the year 2012, out of total shipments of 221.6 million mobile phones, feature phones were 206.4 million units and smart phones were 15.2 million units.

Another example is the online ticket booking facility of the Indian Railways. The Indian Railways Catering and Tourism Corporation (IRCTC), has launched the online ticket booking facility in 2002 and has gained popularity over these years. Here the traveller needs to register free of charge and then is able to book train tickets. IRCTC levies a charge in addition to the cost of tickets for availing this service. In spite of the additional cost involved the website booked a record 0.572 million tickets on $3^{\text {rd }}$ September 2013, showing the increasing popularity of the website (Business Line, 2013). The website can book 2000 tickets per minute and hopes to raise the number to 7200 e-tickets per minute in the current fiscal year 2013-14 (Economic Times, 2013). This acceptance of this high technology service again points to the fact that the service offered is economically appropriate.

An example in the absorption and adoption of high technology and its use in making products that have a cultural, economic and environmental fit is "ChotuKool" by Godrej group, a private sector enterprise in India. In the development of "ChotuKool" a paradigm shift in absorption and adoption of high-technology and making it appropriate for an emerging economy is very much evident. "ChotuKool" is a refrigerator that even though uses high technology, but yet appropriate for an emerging economy like India.

"ChotuKool" a low cost refrigerator designed for India's poorest households, who mostly live in rural areas. 1/3rd of the food is lost in India due to spoilage because of non-affordability of refrigerators. It is these poor households whose income levels are abysmally low and who cannot have proper two square meals a day lose their food. The refrigerators available in markets are too expensive for these households to buy and maintain them. These refrigerators are manufactured based on technologies from the industrialised countries. All the major global manufacturers are offering their range of refrigerators in Indian market, yet the penetration levels are very low in the rural areas.

The development of this low cost refrigerator is based on the needs of the rural population of India and the economic, cultural and environmental 

routine of the villagers - how they purchased, prepared, and stored food and drinks. They concluded that the villagers needed an affordable way to keep milk, vegetables and leftover food cool for a day or two. It is urgent and necessary, as a third of all food is lost due to spoilage as per the United Nations Commission on Sustainable Development. The rural India receives erratic supply of electricity also. The device does not use traditional compressors, but uses a thermoelectric chip (the one used in computers to keep them cool) that maintains a cool temperature on a 12-volt DC current or external battery. It has a top opening, which ensures cold air settles down in the cabinet minimizing heat loss and power consumption, weighing less than $5 \mathrm{KG}$, and having a volume of 45 litres, it is portable and can be carried anywhere (Economic Times, 2011). The colour scheme used is based on the feedback received from "co-creation' events, where the prospective customers were involved.

"ChotuKool" is a high technology device, but the high-technology has been adopted taking into consideration the economic, cultural, social and environmental conditions prevailing in rural India and found ready acceptance. The device also received the 2012 Edison Award Gold prize in the Social Impact category and Godrej was named as one of the world's most innovative companies by Business Week (Economic Times, 2011).

\section{CONCLUSION}

Whether the technology is high or low should not be a debatable issue, but technology that finds acceptance in the emerging economies becomes appropriate. Only those technologies have found acceptance, which take into consideration the economic, cultural, and environmental conditions prevailing in these emerging economies. Hence while selecting / developing new technologies the economic, cultural and environmental conditions prevailing in the economy, where it will be ultimately used needs to be a key consideration. This makes these technologies appropriate and will find acceptance too.

\section{LIMITATIONS}

The study used the case study method and the number of cases needs to be expanded. Also, the cases are from India only. In order to generalize the findings more case studies from other emerging economies need to be considered.

\section{REFERENCES}

Akubue, A. (2000) 'Appropriate Technology for Socioeconomic Development in Third World Countries', The Journal of Technology Studies 26:1, pp. 33-43 (online) (cited 9 March 2013) Available from URL<:http://scholar.lib.vt.edu/ejournals/JOTS/Winter-Spring-2000/ akabue.html> Appropriate Technology in the Age of Renewable (online) (cited on 3 March 2013). Available from <URL: http://www.ncsu.edu/bioresources/BioRes_02/ BioRes_02_2_146_147_Hubbe_AppropriateTechnology.pdf $>$. 
Business Line (2013) '5.72 lakh e-tickets booked on IRCTC Website on a single day', Business Line, 3 September (online) (cited 9 November 2013). Available from <URL: http://www. thehindubusinessline.com/industry-and-economy/logistics/572-lakh-etickets-booked-onirctc-website-on-a-single-day/article5089161.ece>.

Census of India (2011) 'Provisional population totals - India - Data sheet'(online) (cited 8 February 2014). Available from <URL: http://pib.nic.in/prs/2011/latest31mar.pdf>.

Daudpota, Q. I. (2001) 'Intermediate technology - an appropriate developmental path' (online) (cited 6 March 2013). Available from <URL: http://www.sciencevision.org.pk/BackIssues/ Vol7/Vol7No1-2/Vol7No1\&2_9_Intermediate_Technology_IsaDaudpota.pdf $>$.

Economic Times (2011) 'How can you enter an emerging market - and improve the lives of millions?', Economic Times, 22 May (online) (cited 10 December 2012). Available from <URL: $\quad$ http://articles.economictimes.indiatimes.com/2011-05-22/news/29571277_1_ rural-markets-godrej-appliances-infrastructure $>$.

Economic Times (2013) 'IRCTC website to book 7200 tickets per minute', Economic Times, 27 May (online) (cited 9 November 2013). Available from <URL:http://articles. economictimes.indiatimes.com/2013-05-27/news/39557183_1_irctc-website-tatkaltickets-booking-capacity>.

Economist (2008) 'Of internet cafes and power cuts', Economist, 7 February, (online) (cited 6 March 2013). Available from <URL: http://www.economist.com/node/10640716>.

Haug, D. M. (1992) 'The International Transfer of Technology: Lessons that East Europe can learn from the failed Third World experience', Harvard Journal of Law and Technology 5: Spring Issue, pp. 209-240.

Hofstede (2013) 'What about India' (online) (cited 9 November 2013). Available from <URL: http://geert-hofstede.com/india.html>.

Hubbe, M. A. (2007) 'Appropriate Technology in an age of renewable' Bio Resources 2:2, pp. 146-147, (online) (cited 6 March 2013). Available from <URL:http://www.ncsu.edu/ bioresources/BioRes_02/BioRes_02_2_146_147_Hubbe_AppropriateTechnology.pdf>

IBN Live (2013) 'India has 55.48 crore mobile owners, 14.32 crore Internet users', (online) (cited 22 March 2013) Available from <URL: http://ibnlive.in.com/news/india-has-5548-croremobile-owners-1432-crore-internet-users/420444-11.html?utm_source=ref_article>.

Jauhari, V. (2012) 'Innovation through Emergence of Technology Communities: Some Management Lessons', Journal of Technology Management for Growing Economies, 3:2, pp. 89-105.

Merriam -webster (2014) (online) (cited 8 February 2014). Available from<URL: http://www. merriam-webster.com/dictionary/technology

Narayana, N (2003) 'Making Technologies work for the poor in developing countries' Botswana Journal of African Studies, 17:2, pp. 26-34.

Perera, C and Mahakalanda, I (2008) 'Practical Action South Asia "Status of Appropriate / Intermediate Technology Debate and Practice' (online) (cited 6 March 2013). Available from <URL: http://sa-energy.net/filestore/12173118790_forumadmin.pdf>.

Ranis, G. (2011) “Technology and Human Development" (online) (cited 6 March 2013). Available from <URL: http://www.econ.yale.edu/growth_pdf/cdp1004.pdf>.

Sas, L. (2004) 'Appropriate Technology for the Development of the 'Third World', Totem: The University of Western Ontario Journal of Anthropology, 12:1, pp.73-78.

Schumacher, E. F. (1989) Small is beautiful Economics as if people mattered, London, HarperPerennial, a division of Harper Collins Publishers.

Schumacher, E.F. (1993) Small is beautiful Economics as if people mattered, London, Vintage Books.

Solsona, F. (2013), 'Technology, appropriate technology and social factor' (online) (cited 6 March 2013). Available from <URL: http://www.bvsde.paho.org/bvsacg/i/fulltext/ symposium/ponen7.pdf $>$.

Strategy (2008) 'Appropriate technologies in the water sector in the South Africa', Position
Appropriate

Technology and Economic

Development 
Musunuri, D.

paper at Strategy, 8 May (online) (cited 6 March 2013). Available from <URL:http://www. dwaf.gov.za/Masibambane/documents/ATStrategyMay08.pdf>.

Transfer of Technology (2001) 'United Nations Conference on Trade and Development', (online) (cited 12 March 2013). Available from< URL: http://unctad.org/en/Docs/ psiteiitd28.en.pdf>.

Durgamohan Musunuri, Professor and Program Director, Institute for International Management and Technology, Gurgaon, India.

Email: durgamohan27@gmail.com. 